\title{
Lactobacillus and Bifidobacterium Bacteria Profile in Healthy People and People with Type 2 Diabetes Mellitus
}

\author{
Rizki Nurmalya Kardina, Kartika Yuliani, Farah Nuriannisa \\ Nutrition Study Program, Faculty of Health, Nahdlatul Ulama University, Surabaya, Indonesia \\ rizki_kardina@unusa.ac.id \\ DOI: http://doi.org/10.29080/jhsp.v5i1.455
}

Received : October 2020, Accepted : Januari 2021, Published : April 2021

\section{Keywords}

Diabetes;

Bacteria;

Lactobacillus;

Bifidobacterium

\begin{abstract}
Lactobacillus and Bifidobacterium are two genera of gram-positive bacteria that are widely used as probiotic products to improve the composition of the intestinal microbiota but until now the difference in the number of these bacteria in patients with type 2 diabetes mellitus and healthy people in Asia remains unclear. This study conducted a systematic review to analyze the differences in the number of Lactobacillus and Bifidobacterium bacteria in patients with type 2 diabetes and healthy people in Asia. The results showed that the number of Lactobacillus bacteria was higher in patients with type 2 diabetics than in healthy people. The number of Bifidobacterium bacteria in patients with type 2 diabetes tended to be lower than in healthy people, although there was some literature stating that there was no difference in the number of Bifidobacterium bacteria in patients with type 2 diabetes and in healthy people. Further research on the profile of Lactobacillus and Bifidobacterium bacteria per type (species) specifically in people with type 2 diabetes and healthy people of various ethnicities in Indonesia is needed to identify dysbiosis in people with type 2 diabetes and determine specific microbiota therapy for people with type 2 diabetes.
\end{abstract}

\section{Introduction}

Diabetes mellitus type 2 is one of the leading causes of death in Southeast Asia (1). The prevalence of people with type 2 diabetes mellitus in Indonesia based on Riskesdas Data also increases every year, wherein in 2013 it was $6.9 \%$ and increased to $10.9 \%$ in 2018 (2). Type 2 diabetes mellitus is a chronic disease with multifactorial causes, such as diet, lifestyle, and genetic. Several previous studies have also stated that the microbiota in the gastrointestinal tract is also a factor associated with type 2 diabetes mellitus (3). The composition of gut microbiota changes in people with type 2 diabetes mellitus. The number of gram-positive bacteria, such as Lactobacillus and Clostridium (phylum Firmicutes) and Bifidobacterium (phylum Actinobacteria) decrease. While, the number of gram-negative bacteria, such as phylum Bacteroidetes increase (3). A high number of gram-negative bacteria can increase the risk of macro and microvascular complications in people with type 2 diabetes.

Several previous studies have explained that increasing the number of gram-positive bacteria can be done by giving probiotic products, such as yoghurt so that they can improve the balance of the gut microbiota in people with type 2 diabetes mellitus. The results of research conducted by Ejtahed et al (2012) and Ruan et al (2015) stated that there was a decrease in the value of blood glucose and insulin resistance in people with type 2 diabetes mellitus who consumed yoghurt through a mechanism of reducing oxidative stress $(4,5)$. Generally, yoghurt contains Lactobacillus and Bifidobacterium bacteria. Previous research stated that increasing Lactobacillus and Bifidobacterium through yoghurt consumption has benefits for people with type 2 diabetes mellitus. It can produce exopolysaccharides which function as inhibitors of oxidative stress $(6,7)$. However, the effectiveness of using Lactobacillus and Bifidobacterium yoghurt is still questionable. A study conducted by Sato et al. (2014) showed that Lactobacillus bacteria 
tend to increase in people with type 2 diabetes mellitus in Japan, as well as what happened in the population of people with type 2 diabetes mellitus in Europe $(8,9)$. This contradiction result raises a new question about the composition of the microbiota (especially Lactobacillus and Bifidobacterium) among people with type 2 diabetes mellitus.

Considering some of the above factors, we are interested in knowing the differences in the microbiota composition of Lactobacillus and Bifidobacterium in the gut between healthy individuals and people with type 2 diabetes mellitus in the Asian population in a systematic literature review. Consider the results of previous studies suggesting that the composition of Lactobacillus and Bifidobacterium in people with type 2 diabetes mellitus is still not known, especially among Asian include the Indonesian. Besides, the diet and genetics in Asian communities are different from other ethnicities so that they can affect the condition of the microbiota in the gut. The publication of systematic reviews on this topic among Asian populations is still limited. The results of this study are expecting to be one of the theories for the investigation of microbiota composition. Moreover, it becomes one of the bases for the development of alternative therapeutic products (probiotics, prebiotics, or synbiotics) that are compatible with the microbiota composition among people with type 2 diabetes mellitus in the Asia community, especially in Indonesia.

\section{Methods}

This research conducted using a systematic literature review design or method. The search for the data carried out using search engines or databases such as Scopus, PubMed, Science Direct, Springer Link and Google Scholar. The keywords relevant that used in this research following the Boolean rule: "diabetes mellitus type 2 AND probiotic OR Lactobacillus OR Bifidobacterium".

The eligibility criteria for the journals were: 1) examine the composition of the microbiota in the gut, both in healthy individuals and people with type 2 diabetes mellitus; 2) the research respondents are the Asian community or population; 3) Lactobacillus and or Bifidobacterium quantified from stool samples; 4) published during the last 10 years (2011-2020); 5) articles in English or Indonesian, and 6) available in full text. The review method of the scientific research done with the help of the Preferred Reporting Items for Systematic Reviews and Meta-Analysis (PRISMA) checklist. After the search and selection process of literature meets the criteria, the research is continued by synthesizing and analyzing data. The summary made using a table containing information on the name of the researcher, research title, population, methods, results, and conclusions of compatible articles. The contents of the table then are discussed for the conclusion of the systematic review.

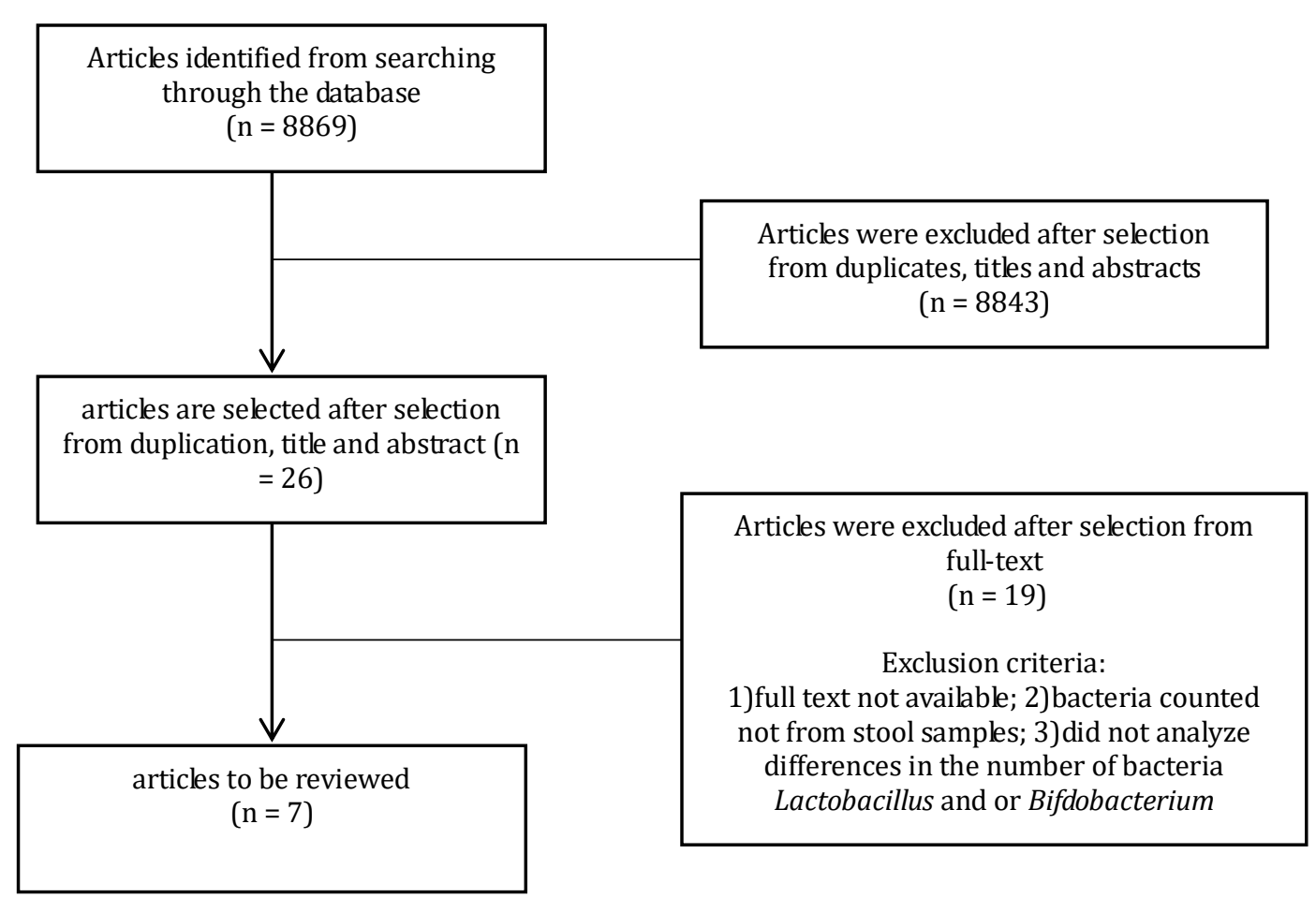

Figure 1. Flowchart of Systematic Literature Search 


\section{Results}

Based on the literature search and selection guidelines, the researcher summarizes the literature search and selection process in Figure 1. A total of 7 articles were eligible for this review. The review listed in Table 1.

Table 1. Journal Reviews

\begin{tabular}{|c|c|c|c|c|c|c|}
\hline \multirow[b]{2}{*}{ Study } & \multirow[b]{2}{*}{ Populations } & \multicolumn{2}{|c|}{ Research method } & \multicolumn{2}{|c|}{ Results } & \multirow[b]{2}{*}{ Conclusion } \\
\hline & & $\begin{array}{c}\text { Study } \\
\text { Desig } \\
\text { n } \\
\end{array}$ & $\begin{array}{c}\text { Bacterial } \\
\text { Count } \\
\text { Method } \\
\end{array}$ & $\begin{array}{c}\text { Type of } \\
\text { Bacteria }\end{array}$ & $\begin{array}{c}\text { The number of } \\
\text { bacteria }\end{array}$ & \\
\hline \multirow[t]{2}{*}{$\begin{array}{l}\text { Hanieh } \\
\text { Sadat } \\
\text { Ejtahed } \\
\text { et al. } \\
(2020)\end{array}$} & \multirow[t]{2}{*}{$\begin{array}{l}49 \text { people with } \\
\text { type } 2 \text { diabetes } \\
\text { mellitus (T2DM), } \\
21 \text { people with } \\
\text { type } 1 \text { diabetes } \\
\text { mellitus (T1DM), } \\
\text { and } 40 \text { healthy } \\
\text { people (control) } \\
\text { in Iran }\end{array}$} & \multirow[t]{2}{*}{$\begin{array}{l}\text { Case } \\
\text { contro } \\
l\end{array}$} & \multirow[t]{2}{*}{$\begin{array}{l}\text { Quantitativ } \\
e \\
\text { polymerase } \\
\text { chain } \\
\text { reaction } \\
\text { (qPCR) 16S } \\
\text { rRNA }\end{array}$} & Lactobacillus & $\begin{array}{l}\text { people with T2DM : } \\
6,8 \pm 0,4 \log 10 \mathrm{CFU} / \mathrm{g} \\
\text { people with } \mathrm{T} 1 \mathrm{DM}: \\
6,8 \pm 0,4 \log 10 \mathrm{CFU} / \mathrm{g} \\
\text { Control : } \quad 4,4 \pm 0,9 \\
\log 10 \mathrm{CFU} / \mathrm{g} \\
p \text {-value }:<0,001^{*}\end{array}$ & $\begin{array}{l}\text { There was a } \\
\text { significant } \\
\text { difference between } \\
\text { the number of } \\
\text { Lactobacillus in } \\
\text { people with T2DM, } \\
\text { T1DM, and healthy } \\
\text { people }\end{array}$ \\
\hline & & & & Bifidobacterium & $\begin{array}{l}\text { people with T2DM : } \\
5,7 \pm 0,9 \log 10 \mathrm{CFU} / \mathrm{g} \\
\text { people with } \mathrm{T} 1 \mathrm{DM}: \\
5,5 \pm 0,8 \log 10 \mathrm{CFU} / \mathrm{g} \\
\text { Control : } \quad 6,0 \pm 1,0 \\
\log 10 \mathrm{CFU} / \mathrm{g} \\
p \text {-value }: 0,04^{*}\end{array}$ & $\begin{array}{l}\text { There was a } \\
\text { significant } \\
\text { difference between } \\
\text { the number of } \\
\text { Bifidobacterium in } \\
\text { people with T2DM, } \\
\text { T1DM, and healthy } \\
\text { people }\end{array}$ \\
\hline \multirow[t]{2}{*}{$\begin{array}{l}\text { Chen et } \\
\text { al. } \\
\text { (2019) }\end{array}$} & \multirow[t]{2}{*}{$\begin{array}{l}50 \text { people with } \\
\text { T2DM and } 50 \\
\text { healthy people } \\
\text { (control) } \\
\text { Taiwan }\end{array}$} & \multirow[t]{2}{*}{$\begin{array}{l}\text { Case } \\
\text { contro } \\
l\end{array}$} & \multirow[t]{2}{*}{$\begin{array}{l}\text { Quantitativ } \\
e \\
\text { polymerase } \\
\text { chain } \\
\text { reaction } \\
\text { (qPCR) 16S } \\
\text { rRNA }\end{array}$} & Lactobacillus & $\begin{array}{l}\text { people with T2DM : } \\
4,9 \pm 1,1 \log 10 / g \\
\text { Control : } 4,2 \pm 1,2 \\
\log 10 / g \\
p \text {-value }: 0,0005^{*}\end{array}$ & $\begin{array}{l}\text { There was a } \\
\text { significant } \\
\text { difference between } \\
\text { the number of } \\
\text { Lactobacillus in } \\
\text { people with T2DM } \\
\text { and healthy people }\end{array}$ \\
\hline & & & & Bifidobacterium & $\begin{array}{l}\text { people with T2DM : } \\
6,8 \pm 1,5 \log 10 / g \\
\text { Control : } 7,0 \pm 1,1 \\
\log 10 / g \\
p \text {-value }: 0,482\end{array}$ & $\begin{array}{l}\text { There was no } \\
\text { significant } \\
\text { difference between } \\
\text { the number of } \\
\text { Bifidobacterium in } \\
\text { people with T2DM } \\
\text { and healthy people }\end{array}$ \\
\hline $\begin{array}{l}\text { Adachi } \\
\text { et al. } \\
(2019)\end{array}$ & $\begin{array}{l}59 \text { people with } \\
\text { T2DM and } 59 \\
\text { healthy people } \\
\text { (controls) } \\
\text { Japan }\end{array}$ & $\begin{array}{l}\text { Case } \\
\text { contro } \\
l\end{array}$ & $\begin{array}{l}\text { polymerase } \\
\text { chain } \\
\text { reaction } \\
\text { (PCR) 16S } \\
\text { rDNA }\end{array}$ & Bifidobacterium & $\begin{array}{l}\text { people with T2DM : } \\
25,7 \quad(12,4-38,5) \\
\text { (Population, \% total } \\
\text { sequences) } \\
\text { Control: } 5,5 \quad(1,5- \\
\text { 12,0) (Population, \% } \\
\text { total sequences) } \\
\text { p-value: }<0,01^{*}\end{array}$ & $\begin{array}{l}\text { There was a } \\
\text { significant } \\
\text { difference between } \\
\text { the number of } \\
\text { Bifidobacterium in } \\
\text { people with T2DM } \\
\text { and healthy people }\end{array}$ \\
\hline \multirow[t]{2}{*}{$\begin{array}{l}\text { Sedighi } \\
\text { et al. } \\
(2017)\end{array}$} & \multirow[t]{2}{*}{$\begin{array}{l}18 \text { people with } \\
\text { T2DM and } 18 \\
\text { healthy people } \\
\text { (controls) in Iran }\end{array}$} & \multirow[t]{2}{*}{$\begin{array}{l}\text { Case } \\
\text { contro } \\
l\end{array}$} & \multirow[t]{2}{*}{$\begin{array}{l}\text { Quantitativ } \\
e \\
\text { polymerase } \\
\text { chain } \\
\text { reaction } \\
\text { (qPCR) 16S } \\
\text { rRNA }\end{array}$} & Lactobacillus & $\begin{array}{l}\text { people with T2DM : } \\
6,65 \mathrm{E} 6 \pm 2,02 \mathrm{E} 6 / \mathrm{g} \\
\text { Control : } 1,22 \mathrm{E} 6 \pm \\
6,51 \mathrm{E} 5 / \mathrm{g} \\
p \text {-value }: 0,00^{*}\end{array}$ & $\begin{array}{l}\text { There was a } \\
\text { significant } \\
\text { difference between } \\
\text { the number of } \\
\text { Lactobacillus in } \\
\text { people with T2DM } \\
\text { and healthy people }\end{array}$ \\
\hline & & & & Bifidobacterium & $\begin{array}{l}\text { people with T2DM : } \\
1,82 \mathrm{E} 7 \pm 1,88 \mathrm{E} 7 / \mathrm{g} \\
\text { Control : } 5,24 \mathrm{E} 8 \pm \\
1,36 \mathrm{E} 7 / \mathrm{g} \\
p \text {-value }: 0,00^{*}\end{array}$ & $\begin{array}{l}\text { There was a } \\
\text { significant } \\
\text { difference between } \\
\text { the number of } \\
\text { Bifidobacterium in } \\
\text { people with T2DM } \\
\text { and healthy people }\end{array}$ \\
\hline
\end{tabular}


Table 1. Journal Reviews (Cont.)

\begin{tabular}{|c|c|c|c|c|c|c|}
\hline \multirow[b]{2}{*}{ Study } & \multirow[b]{2}{*}{ Populations } & \multicolumn{2}{|c|}{ Research method } & \multicolumn{2}{|c|}{ Results } & \multirow[b]{2}{*}{ Conclusions } \\
\hline & & $\begin{array}{c}\text { Study } \\
\text { Design }\end{array}$ & $\begin{array}{c}\text { Bacterial } \\
\text { Count } \\
\text { Method }\end{array}$ & $\begin{array}{l}\text { Type of } \\
\text { Bacteria }\end{array}$ & $\begin{array}{l}\text { The number of } \\
\text { bacteria }\end{array}$ & \\
\hline \multirow{5}{*}{$\begin{array}{l}\text { Navab- } \\
\text { Moghad } \\
\text { am et } \\
\text { al. } \\
\text { (2017) }\end{array}$} & \multirow{5}{*}{$\begin{array}{l}18 \text { people with } \\
\text { T2DM and } 18 \\
\text { healthy people } \\
\text { (controls) in } \\
\text { Iran }\end{array}$} & \multirow{5}{*}{$\begin{array}{l}\text { Case } \\
\text { control }\end{array}$} & \multirow{5}{*}{$\begin{array}{l}\text { Quantitative } \\
\text { polymerase } \\
\text { chain } \\
\text { reaction } \\
\text { (qPCR) 16S } \\
\text { rDNA }\end{array}$} & B. fragilis & people with T2DM : & $\begin{array}{l}\text { There was no } \\
\text { significant }\end{array}$ \\
\hline & & & & & transformation) & difference between \\
\hline & & & & & $\begin{array}{l}\text { Control: } \quad 1,59 \pm 1,63 \\
\text { (After } \\
\text { transformation) } \\
p \text {-value: } 0,38\end{array}$ & $\begin{array}{l}\text { the number of } B \text {. } \\
\text { fragilis in people } \\
\text { with T2DM and } \\
\text { healthy people }\end{array}$ \\
\hline & & & & B. Longum & $\begin{array}{l}\text { people with T2DM : } \\
1,08 \pm 0,74 \text { ( After data } \\
\text { transformation ) }\end{array}$ & $\begin{array}{l}\text { There was no } \\
\text { significant } \\
\text { difference between }\end{array}$ \\
\hline & & & & & $\begin{array}{l}\text { Control: } \quad 1,08 \pm 0,76 \\
\text { (After } \\
\text { transformation ) } \\
p \text {-value }: 0,93\end{array}$ & $\begin{array}{l}\text { the number of } B . \\
\text { Longum in people } \\
\text { with T2DM and } \\
\text { healthy people }\end{array}$ \\
\hline \multirow[t]{3}{*}{$\begin{array}{l}\text { Sato et } \\
\text { al. } \\
\text { (2014b) }\end{array}$} & \multirow[t]{3}{*}{$\begin{array}{l}50 \text { people with } \\
\text { type } 2 \text { diabetes } \\
\text { mellitus and } 50 \\
\text { healthy people } \\
\text { (control) in } \\
\text { Japan }\end{array}$} & \multirow[t]{3}{*}{$\begin{array}{l}\text { Case } \\
\text { control }\end{array}$} & \multirow[t]{3}{*}{$\begin{array}{l}\text { 16S rRNA- } \\
\text { targeted } \\
\text { RT- } \\
\text { quantitative } \\
\text { PCR (qPCR) }\end{array}$} & Lactobacillus & $\begin{array}{l}\text { people with T2DM: } \\
7,0 \pm 1,5 \log 10 \mathrm{sel} / \mathrm{g} \\
\text { Control: } 6,4 \pm 1,2 \log 10 \\
\text { sel/g } \\
p \text {-value }:<0,05^{*}\end{array}$ & $\begin{array}{l}\text { There was a } \\
\text { significant difference } \\
\text { between the number } \\
\text { of Lactobacillus in } \\
\text { people with T2DM } \\
\text { and healthy people }\end{array}$ \\
\hline & & & & $\begin{array}{l}\text { Bifidobacteri } \\
\text { um }\end{array}$ & $\begin{array}{l}\text { people with T2DM: } \\
9,2 \pm 0,8 \log 10 \mathrm{sel} / \mathrm{g}\end{array}$ & $\begin{array}{l}\text { There was no } \\
\text { significant difference }\end{array}$ \\
\hline & & & & & $\begin{array}{l}\text { Control: } \quad 9,2 \pm 0,8 \\
\log 10 \mathrm{sel} / \mathrm{g} \\
p \text {-value }:>0,05\end{array}$ & $\begin{array}{l}\text { between the number } \\
\text { of Bifidobacterium in } \\
\text { people with T2DM } \\
\text { and healthy people }\end{array}$ \\
\hline \multirow[t]{4}{*}{$\begin{array}{l}\text { Lê et al. } \\
\text { (2013) }\end{array}$} & \multirow[t]{4}{*}{$\begin{array}{l}50 \text { people with } \\
\text { type } 2 \text { diabetes } \\
\text { mellitus and } 30 \\
\text { healthy people } \\
\text { in South China }\end{array}$} & \multirow[t]{4}{*}{$\begin{array}{l}\text { Case } \\
\text { control }\end{array}$} & \multirow[t]{4}{*}{$\begin{array}{l}\text { Quantitative } \\
\text { polymerase } \\
\text { chain } \\
\text { reaction } \\
\text { (qPCR) }\end{array}$} & Lactobacillus & $\begin{array}{l}\text { people with T2DM: } \\
7,8 \pm 0,9 \text { (Data after } \\
\text { logarithm } \\
\text { transformation) }\end{array}$ & $\begin{array}{l}\text { There was a } \\
\text { significant difference } \\
\text { between the number } \\
\text { of Lactobacillus in }\end{array}$ \\
\hline & & & & & $\begin{array}{l}\text { Healthy people } \\
\text { (control) : } 6,6 \pm 0,5 \\
\text { (Data after logarithm } \\
\text { transformation) } \\
p \text {-value: }<0,0001^{*}\end{array}$ & $\begin{array}{l}\text { people with T2DM } \\
\text { and healthy people }\end{array}$ \\
\hline & & & & $\begin{array}{l}\text { Bifidobacteri } \\
\text { um }\end{array}$ & $\begin{array}{l}\text { people with T2DM: } \\
10,7 \pm 0,7 \text { (Data after } \\
\text { logarithm } \\
\text { transformation) }\end{array}$ & $\begin{array}{l}\text { There was a } \\
\text { significant difference } \\
\text { between the number } \\
\text { of Bifidobacterium in }\end{array}$ \\
\hline & & & & & $\begin{array}{l}\text { Control : } 11,6 \pm 0,9 \\
\text { (Data after logarithm } \\
\text { transformation) } \\
p \text {-value : }<0,0001^{*}\end{array}$ & $\begin{array}{l}\text { people with T2DM } \\
\text { and healthy people }\end{array}$ \\
\hline
\end{tabular}

Note: $*$ there is a significant difference $(\mathrm{p}<0.05)$

\section{Discussion}

Following the objectives of the study, the researchers reviewed the differences in the number of Lactobacillus and Bifidobacterium bacteria in healthy people and people with type 2 diabetes in Asia. Lactobacillus and Bifidobacterium are two genera of gram-positive bacteria that commonly exist in the human digestive tract (10). Four articles analyzed the difference in the number of Lactobacillus bacteria between people with type 2 diabetes mellitus (type 2 diabetes) and healthy people in Asia. An article analyzed the difference in the number of Lactobacillus bacteria between people with type 2 diabetes, type 1 diabetes mellitus and healthy people in Asia. All articles conclude that there are differences in the number of Lactobacillus bacteria between people with type 2 diabetes and healthy people and there are differences in the number of Lactobacillus bacteria between people with type 2 diabetes, people with type 1 diabetes, and healthy people. In general, all articles show that the number of Lactobacillus bacteria is higher in people with type 2 diabetes than in healthy people.

According to previous research, not all bacteria from the genus Lactobacillus have a positive effect on people with type 2 diabetes. Lactobacillus is a genus that has a positive response on modulating blood 
glucose, while for another genus has different effects $(11,12)$. Based on these reasons, the researchers suggest further research to identify differences in the number of bacteria from the Lactobacillus genus per type so that the research results are detailed.

Other possibilities could be the cause of the higher number of genus Lactobacillus bacteria in people with type 2 diabetes mellitus compared to healthy people. The intestinal microbiota influenced by the type of drug consumed in people with type 2 diabetes mellitus (13). Several previous studies or reviews stated that there is a tendency to decrease the number of Lactobacillus bacteria in the gastrointestinal tract of people with type 2 diabetes. But, this may change if the patient starts to conduct new habits such as eating high-probiotic foods, high-fibre foods and or taking anti-hyperglycemic drugs. High-probiotic foods such as yoghurt, kefir, cheese, or milk and foods high in insoluble fibre have shown to increase the number of Lactobacillus bacteria in the digestive tract (14).

When viewed from the population characteristics of the articles reviewed, there is a tendency for the habit of eating foods high in probiotics among Iranian, Japanese, and parts of Chinese . All three populations of these countries have long had a culture of consuming a high probiotic diet, which probiotic products accessed easily from pharmacies and health facilities (22). Japan is known as the global market leader in the field of probiotics. Japanese usually consume products high in probiotics for health (22). The results of a review of research in Iran also show that Iranians have begun to realize the importance of consuming foods or products high in probiotics so that the need for food or probiotic products increases (23). The tradition of changing milk into fermented products has also long been applied in China so that Chinese people are most likely already accustomed to consuming fermented milk that contains probiotics, one of which is the genus Lactobacillus (24). These reasons can be the cause of the higher number of Lactobacillus bacteria in people with type 2 diabetes than in healthy people.

The review of the number of Bifidobacterium bacteria among people with type 2 diabetes and healthy people in Asia obtained from 5 journals. One journal analyzed the differences in the number of Bifidobacterium bacteria in people with type 2 diabetes, people with type 1 diabetes, and healthy people showed the results that the number of Bifidobacterium was higher in healthy people than in people with type 2 and type 1 diabetes. Three journals concluded that there was a significant difference in the number of Bifidobacterium bacteria in people with type 2 diabetes and healthy people. Moreover, two journals showed that the number of Bifidobacterium bacteria was higher in the control group (healthy people) compared to the group of people with type 2 diabetes mellitus. Otherwise, a journal shows the opposite result. Two journals that analyzed the difference in the number of Bifidobacterium bacteria between the two groups showed insignificant differences. In general, it concluded that there is still debate about the number of Bifidobacterium bacteria in people with type 2 diabetes and healthy people. However, when compared with previous studies, it can be concluded that there is a tendency for the number of Bifidobacterium bacteria to be higher in the digestive tract of healthy people compared to people with type 2 diabetes. This evidence was not remarkable because the bacteria of the genus Bifidobacterium have antiinflammatory effects which people with dietary habits are high in fat and people with metabolic disorders such as diabetes mellitus will experience a decrease in the composition of the bacterial genus Bifidobacterium $(25,26)$.

The decrease in the number or composition of Bifidobacterium bacteria in people with type 2 diabetes may not always occur because generally, the number of each type of the genus Bifidobacterium is also different. Based on another article that reviewed, it showed that the number of bacteria with the species Bifidobacterium fragilis and Bifidobacterium longum did not differ significantly in the digestive tract of people with type 2 diabetes mellitus and healthy people. The results of these studies differ from the study of Le et al (2013), which showed that there was a significant difference in the number of Bifidobacterium adolescentis bacteria in the digestive tract of people with type 2 diabetes and healthy people. There is a tendency for the higher number of Bifidobacterium adolescentis in the digestive tract of healthy people (21). The results of the study which state that there is a significant difference between the number of Bifidobacterium bacteria with type 2 diabetes mellitus and healthy people are generally consistent with the result of the number of bacteria from the genus Bifidobacterium is higher in healthy people than people with type 2 diabetes $(15,18)$. This study is indeed limited in reviewing the differences between Lactobacillus and Bifidobacterium bacteria because it only analyzes genus, even though the effects of probiotics are broad and vary depending on the probiotic type. Therefore, researchers suggest further research on the number of type of bacteria from the genus Bifidobacterium and Lactobacillus in people with type 2 diabetes mellitus and healthy people. We also recommend that microbiota-based therapy for people with type 2 diabetes be developed, especially from the genus Bifidobacterium and several types of Lactobacillus, which do have a positive effect on reducing blood glucose. Because there has been no research on a topic like this in Indonesia, we also suggest that a specific study be conducted to observe the number of Bifidobacterium and Lactobacillus bacteria in people with type 2 diabetes mellitus and healthy people in Indonesia. 


\section{Conclusion}

This Systematic Literature Review study concludes that there is a difference in the number of Lactobacillus bacteria in the digestive tract of people with type 2 diabetes and healthy people in Asia populations. There is also a tendency for the number of Lactobacillus bacteria in the digestive tract of people with type 2 diabetes to be greater than in healthy people. Based on an article that reviewed, there is still debate about the difference in the number of Bifidobacterium bacteria in the digestive tract of people with type 2 diabetes and healthy people. But the results of studies show that there are differences in the number of Bifidobacterium bacteria in the digestive tract of people with type 2 diabetes and healthy people in Asian populations. It consistently shows a decrease in the number of Bifidobacterium bacteria in the digestive tract of people with type 2 diabetes. Further research on the profile of Lactobacillus and Bifidobacterium bacteria per type (species) specifically in people with type 2 diabetes and healthy people of various ethnicities in Indonesia is needed to identify dysbiosis in people with type 2 diabetes. Further study also be required to determine specific microbiota therapy for people with type 2 diabetes.

\section{Acknowledgments}

Researchers would like to thank the Ministry of Education and Culture of the Republic of Indonesia for the Beginner Lecturer Research Grant provided for funding this research.

\section{References}

1. WHO. Diabetes Fakta dan Angka. 2016.

2. $\quad$ Kementerian Kesehatan RI. Laporan Nasional RISKESDAS 2018. 2018.

3. Sharma S, Tripathi P. Gut microbiome and type 2 diabetes: where we are and where to go? Vol. 63 , Journal of Nutritional Biochemistry. Elsevier Inc.; 2019. p. 101-8.

4. Ejtahed HS, Mohtadi-Nia J, Homayouni-Rad A, Niafar M, Asghari-Jafarabadi M, Mofid V. Probiotic yogurt improves antioxidant status in type 2 diabetic patients. Nutrition. 2012 May 1;28(5):539-43.

5. Ruan Y, Sun J, He J, Chen F, Chen R, Chen H. Effect of probiotics on glycemic control: A systematic review and meta-analysis of randomized, controlled trials. PLoS One [Internet]. 2015 Jul 10 [cited 2020 Sep 18];10(7). Available from: https://pubmed.ncbi.nlm.nih.gov/26161741/

6. Prasanna PHP, Grandison AS, Charalampopoulos D. Bifidobacteria in milk products: An overview of physiological and biochemical properties, exopolysaccharide production, selection criteria of milk products and health benefits. Vol. 55, Food Research International. Elsevier Ltd; 2014. p. 247-62.

7. Yerlikaya O. Starter cultures used in probiotic dairy product preparation and popular probiotic dairy drinks. Food Sci Technol [Internet]. 2014 [cited 2020 Sep 18];34(2):221-9. Available from: http://dx.doi.org/10.1590/fst.2014.0050

8. Sato J, Kanazawa A, Ikeda F, Yoshihara T, Goto H, Abe H, et al. Gut dysbiosis and detection of "Live gut bacteria" in blood of Japanese patients with type 2 diabetes. Diabetes Care. 2014;37(8):2343-50.

9. He C, Shan Y, Song W. Targeting gut microbiota as a possible therapy for diabetes. Vol. 35, Nutrition Research. Elsevier Inc.; 2015. p. 361-7.

10. Turroni F, Ventura M, Buttó LF, Duranti S, O'Toole PW, Motherway MOC, et al. Molecular dialogue between the human gut microbiota and the host: A Lactobacillus and Bifidobacterium perspective [Internet]. Vol. 71, Cellular and Molecular Life Sciences. Springer; 2014 [cited 2020 Sep 18]. p. 183203. Available from: https://link.springer.com/article/10.1007/s00018-013-1318-0

11. Wang G, Li X, Zhao J, Zhang H, Chen W. Lactobacillus casei CCFM419 attenuates type 2 diabetes via a gut microbiota dependent mechanism. Food Funct [Internet]. 2017 Sep 1 [cited 2020 Sep 18];8(9):315564. Available from: https://pubs.rsc.org/en/content/articlehtml/2017/fo/c7fo00593h

12. Yan F, Li N, Shi J, Li H, Yue Y, Jiao W, et al. Lactobacillus acidophilus alleviates type 2 diabetes by regulating hepatic glucose, lipid metabolism and gut microbiota in mice. Food Funct [Internet]. 2019 Sep 1 [cited 2020 Sep 18];10(9):5804-15. Available from: https://pubs.rsc.org/en/content/articlehtml/2019/fo/c9fo01062a

13. Kałużna-Czaplińska J, Gątarek P, Chartrand MS, Dadar M, Bjørklund G. Is there a relationship between intestinal microbiota, dietary compounds, and obesity? Trends Food Sci Technol. 2017;70(July):105-13.

14. Namdag B, Batdelger A, Batsaikhan S, Chimeddorj B. Determination Result of Colonic Lactobacillus in Healthy Adults. 2019;5(2):149-56.

15. Ejtahed HS, Hoseini-Tavassol Z, Khatami S, Zangeneh M, Behrouzi A, Ahmadi Badi S, et al. Main gut bacterial composition differs between patients with type 1 and type 2 diabetes and non-diabetic adults. $\mathbf{J}$ Diabetes Metab Disord. 2020;19(1):265-71.

16. Chen P-C, Chien Y-W, Yang S-C. The Alteration of Gut Microbiota in Newly Diagnosed Type 2 Diabetic Patients. Nutrition. 2019;63-64:51-6.

17. Adachi K, Sugiyama To, Yamaguchi Y, Tamura Y, Izawa S, Hijikata Y, et al. Gut Microbiota Disorders 
Cause Type 2 Diabetes Mellitus and Homeostatic Disturbances in Gut-related Metabolism in Japanese Subjects. J Clin Biochem Nutr. 2019;

18. Sedighi M, Razavi S, Navab-Moghadam F, Khamseh ME, Alaei-Shahmiri F, Mehrtash A, et al. Comparison of gut microbiota in adult patients with type 2 diabetes and healthy individuals. Microb Pathog [Internet]. 2017;111:362-9. Available from: https://doi.org/10.1016/j.micpath.2017.08.038

19. Navab-Moghadam F, Sedighi M, Khamseh ME, Alaei-Shahmiri F, Talebi M, Razavi S, et al. The association of type II diabetes with gut microbiota composition. Microb Pathog [Internet]. 2017;110:630-6. Available from: http://dx.doi.org/10.1016/j.micpath.2017.07.034

20. Sato J, Kanazawa A, Ikeda F, Yoshihara T, Goto H, Abe H, et al. Gut dysbiosis and detection of "Live gut bacteria" in blood of Japanese patients with type 2 diabetes. Diabetes Care [Internet]. 2014 Aug 1 [cited 2020 Sep 18];37(8):2343-50. Available from: http://care.diabetesjournals.org/lookup/

21. Lê KA, Li Y, Xu X, Yang W, Liu T, Zhao X, et al. Alterations in fecal Lactobacillus and Bifidobacterium species in type 2 diabetic patients in Southern China population. Front Physiol. 2013;3 JAN(January):16.

22. Amagase H. Current marketplace for probiotics: A Japanese perspective. Clin Infect Dis. 2008;46(SUPPL. 2):73-5.

23. Mahmoudi R, Tahapour K, Farhoodi A, Fakhri O, Kaboudari A. A Review on Probiotic Dairy Products as Functional Foods Reported from Iran. Int J Food Nutr Saf. 2015;6(3):94-105.

24. Mullie P, Guelinckx I, Clarys P, Degrave E, Hulens M, Vansant G. Cultural, socioeconomic and nutritional determinants of functional food consumption patterns. Eur J Clin Nutr [Internet]. 2009 Aug 26 [cited 2020 Sep 18];63(11):1290-6. Available from: www.nature.com/ejcn

25. Kawasaki S, Watanabe M, Fukiya S, Yokota A. Stress Responses of Bifidobacteria: Oxygen and Bile Acid as the Stressors. In: The Bifidobacteria and Related Organisms. Elsevier; 2018. p. 131-43.

26. Lin Y, Ren Y, Zhang Y, Zhou J, Zhou F, Zhao Q, et al. Protective role of nano-selenium-enriched Bifidobacterium longum in delaying the onset of streptozotocin-induced diabetes. R Soc Open Sci [Internet]. 2018 Dec 12 [cited 2020 Sep 18];5(12):181156. Available from: https://royalsocietypublishing.org/doi/10.1098/rsos.181156 